\title{
Turkey's Northern Iraq Policy Within the Dilemma of National Security Problems and Economic Cooperation (2003-2015)
}

\author{
A. Sait Sonmez, Assist. Prof. Dr. \\ Samed Kurban, Research Assistant
}

Ondokuz Mayıs University, Faculty of Economics and Administrative Sciences, Department of Political Science and Public Administration

doi: 10.19044/esj.2016.v13n2p13 URL:http://dx.doi.org/10.19044/esj.2016.v13n2p13

\begin{abstract}
The general characteristic of the foreign policy adopted by Turkey for North Iraq has been shaped based on the national integrity of Iraq since the Gulf War ${ }^{4}$. However developments in this country caused an increase in seperation demands from North Iraq Kurds. On the other hand this region had become an important base for Kurdish Workers Party (PKK) since 1980's. Turkey's security dilemma and priorities over Iraq were formulated as "red lines" and decleraded before invasion of Iraq. But North Iraq based security issues increased after the occupation of Iraq by the United States of America (USA). Getting support of the USA Iraqi Kurds began to follow a policy as political rival of Turkey. But economic relations, which have been established with the regional Government in terms of energy and trade, caused cooperation in other fields. So transfomation of bilateral relations of Turkey and Kurdish Regional Government of Iraq (KRGI) is discussed in this paper. Aim of this paper is to analyze how economic cooperation caused cooperation in security issues such as fight against terrorism.
\end{abstract}

Keywords: Northern Iraq, Turkish Foreign Policy, National Security Issues, Economic Cooperation

\section{Introduction}

Turkey is a an important regional actor with its 75 million population in the regions such as Middle East, Balkans and the Caucasus. Historical and geopolitical realities force Turkey to follow active foreign policy in these regions. From the historical perspective Turkey has close links with these

\footnotetext{
${ }^{4}$ The war that was forced Iraq to end occupation of Kuwait by the coalition under the USA leadership in 1991.
} 
regions inhabited from Ottomans. On the other hand Turkey is located just at the center of Afro Eurasia geography so developments in these regions directly affect Turkey. After the Cold War Turkey had to reshape its foreign and security policies towards the crisis such as Bosnia, Nagorno Karabakh etc. In this paper Northern Iraq dimension of Turkey’s foreign policy will be discussed.

Within the period from the establishment of autonomous regime in 1992 to our day, Turkey's Northern Iraq policy is grouped in three periods. Between 1992 and 2003, which is the first period, Turkey followed a security based policy in the area. This policy had two important strategic goals: destructing PKK settlement in the area and protecting the territorial integrity of Iraq. However, there is a point to emphasize here, both PKK's settlement becoming stonger in the area and the emergence of the danger of separation for Iraq were a "consequent" result of the activities of the "combined task force" that was settled in South of Turkey with the demand of Ankara. Allowing the deployment of the combined task force in the country for humanitarian reasons protected Kurds from the attacks of Saddam on the one hand while paving the way for an actual power settlement in the region on the other hand. However, Turkey increased its military and political power in the area for the sake of fighting PKK. After taking the area under control, Ankara tried to restrain the independence demands of Kurdish leaders in the area on the one hand, while at the same time developing common policies with Baghdad, Tehran and Damascus for this purpose.

This Northern Iraq policy of Turkey, which was carried out on a delicate balance, collapsed with the invasion of Iraq by the USA in 2003 and a new period started in Turkey's Northern Iraq policy. Due to their role within the invasion process, Kurds became the USA's closest ally in Iraq and thus they achieved important gains after the war. In addition, one of the most important crises in the recent period occured in Turkish-American relations and consequently Turkey's military and political influence in Northern Iraq diminished gradually. However, Turkey’s trading activities in Northern Iraq increased in this period and an economic dependence formed between Ankara and Erbil (administration center of Kurdish Regional Goverment of Iraq (KRGI)), as a result of this.

The third period started in 2008 in Turkey's Northern Iraq policy with the changes in the USA's Iraq policy and the decision to reorganize the bilateral relations by Ankara and Erbil. In this period, the economic and trading cooperation between Turkey and KRGI also began to be seen in the areas of defence and politics. Ankara and Erbil reached an agreement about fighting terrorist organizations such as PKK and Iraq and Leviethan State (ILS). The cooperation between Ankara and Erbil in some areas, mainly 
energy, began to bother Baghdad. The main theme of the study is to analyze the transformation of Turkey's Northern Iraq policy within the period after invasion, the outline of which is given above.

\section{Theoretical Framework: Conceptual Discussions About National Security Problems}

Realism and political liberalism, which are the two important paradigms of international relations discipline, approach international security problems from different perspectives, like they approach many other subjects. Also it must be mentioned here that debates between these two schools caused emergence of international relations as a new dicipline (see Eralp, 57-89: 2000). The logic behind these two schools' analyzing international politics goes back to Grotian/Kantian and Hobbesian/Machiavellist traditions (Eralp, 2000:58). Authors such as Hobbes, Machievelli and Rousseau, who prepared the substructure for realist thinking claimed that "nations try to provide their security at the expense of their neighbours" and that "international relations are power struggle". According to classical realists such as H.Carr and H.Morgenthau, since it is not possible to ensure a permanent peace in a Kantian sense, "what nations can do is to try to balance the power of other nations in order to prevent one nation from gaining full hegemony". According to neo realist authors such as K.Waltz and J.Mearsheimer, to a great extent, security problems among nations are caused by the "anarchical" structure that is always present in the international system. Cooperation between nations can only exist in a limited way, competition resulting from security problems define this limit. A real long term peace or a world in which nations do not compete for power is impossible (Baylis, 2008: 71-72).

Classical realists have stated that the basic factors which influence the foreign policy of nations are "national interest" and "security problems". Realists, who define the sum of individuals' security as national security, have associated security problems with military power, especially in studies they conducted in the period of Cold War. If an issue was not about "military power", then they tended not to see it as a "security problem" (Tanrisever, 2005: 109-110). According to this perspective, maintaining security and fulfilling national interests could be possible only through military power. Realists considered having military power and increasing military power capacity, even using this capacity if needed, as a significant strategic target. This approach, which considered the state as the primary actor, advocated the determination of security policies in line with military strategies and claimed that security against potential threats could only be ensured through military power (Bakan, 2007: 39). This importance placed on security problems by realists can be understood from their naming this issue as high 
politics and every other issue, including economic issues, as low politics. It should also be emphasized that realists consider international relations as "zerosum game". According to this claim, which is also analyzed by game theoreticians, the gain of one side means the loss of the other side because interests of nations are in conflict with each other rather than being in harmony (Mearsheimer, 2002: 25). Realist approach bases the reason of conflicts between nations on reasons such as power increase between independent political units or search for security. According to this group, peace which emerges as a result of the settlement of the tension is possible. However, this situation does not mean that there is no international competition. Peace is only secured through the balance of power system that occurs when the expansionist policies of one side are restrained by the opposite side (Tellis, 2006-07: 3).

Thoughts which are contrary to the views of realism about international affairs and international security, which have shortly been mentioned above, have been suggested by Political Liberals who are also known as Idealists. Theories such as transnationalism, interdependence, pluralism and multilateralism, which are influenced by idealism, have also made claims about this issue, which are similar to the views of liberalism. These theories point out that non-state actors also influence international politics and they approach the issue of security from a different perspective. Economic and social issues have become vital like global security problems. Like conflict, cooperation can also come to the forefront in international relations. Especially in the event of the emergence of an interdependence relation, joint interests cause nations to come together. Hence, cooperation between nations cause the emergence of prosperity and stability in the international system. Transnationalists/liberals claim that nations do not act by applying "power policy” only in accordance with their national interests. In addition, unlike realists, liberalists advocate that international policy issues cannot be simply grouped in two as "high" and "low" importance. Liberals accept that issues such as military power and national security, which are called high policy by realists, are undoubtedly vital issues in international arena. However, according to liberals, just like security issues, economic, social and environmental issues are also "vital” (Rana, 2015: 291).

According to transnationalism, general characteristics of international relations are in fact more prone to cooperation than conflict. Widespread democratic governance and values and increase in economic interdependency cause a decrease in international conflicts and an increase in long term cooperation. Thus, prevalence of democracy results with the spread of peace. Transnationalists state that within international law, there are rules that interest the nations themselves and these rules cause the 
emergence of the law community that govern the actions of these states (Canestaro, 2007: 115). A great number of political scientists who have been influenced by the theory of liberal international relations claim that increasing international trade and interdependence will cause international peace. In fact, they developed a modern research method using quantitative statistical data to prove this view that goes back to classical liberal philosophers such as Adam Smith and Immanuel Kant. As a result of studies conducted with this method, they concluded that economic interdependency increases international peace. Statistical results about this subject prove a simple generalization. As a result of increase in international trade, cross border (in the production of specific products) specialization also increases. With the increasing specialization, the profit that comes from the trade and interdependency also deepen. Another result emerges in this case; a war between nations that have interdependency relations is more costly. Thus, it becomes difficult for nations to allocate resources for military power (Tellis, 2006-07: 6). There are also views that the arms race, which is in the background of wars, will decrease or disappear in parallel with the increase in interdependency (Sancak, 127). The importance of construction of international agencies is also emphasized about ending wars. From this point of view, according to "Liberal theorists", "international agencies that are active on a reciprocal basis can be the element of a sustainable peace. Although liberal theorists do not believe that it is possible for international agencies to eliminate war, they advocate that they can help to build stronger international cooperation" (Baylis, 2008: 78). Within the context of international law, legal obligations of nations come to light. These obligations also result in the emergence of law-based societies which govern the relations of their own nations. International law puts forward that norms and regimes develop and in return, nations' sovereignty decreases evolutionarily in line with international legal norms. International cooperation, on the other hand, causes increase in universal human values such as justice, human rights and equality (Canestaro, 2007: 115).

In addition to these, integration theorists such as K.Deutsch, E.Haas and A.Etizoni claim that international cooperation in various areas, mainly economic and trading issues, will result in political integration. Törnud emphasizes that integration will occur in three different levels as political, economic, military and communication areas. Haas states that economic and institutional cooperation between nations will "pave the way for peace based political solutions”. Haas explains this with the concept of 'spill-over'. Deutsch claims that integration can occur when the political elite respond to demands put forward by nations and to problems that can be dealt with when nations act together. In response to Haas’s “spill-over” concept, Deutsch uses 
the "take-off" concept for the process in which security society will emerge (cited from Canbolat, 2002: 103-107).

The views summarized in short above explain the transformation in Turkey's Northern Iraq policy following the invasion of Iraq. So it will be analyzed how economic cooperation affected security issues such as fight against terrorism.

\section{Turkey's Northern Iraq Policy After the Invasion of Iraq} The Period of National Security based Northern Iraq Policy (2003-2007)

With the invasion of Iraq, regional balances changed in the Middle East and the countries in the region, mainly Turkey, developed home and foreign security strategies to reduce the possible problems the invasion would cause to a minimum level. Ankara declared its priorities against possible developments that may arise after the invasion as "red lines". Within this period, these "red lines" constituted the basis of Turkey's Northern Iraq policy. In the June and July of 2002, when the invasion was close, a committee that was formed by military and civilian bureaucracy prepared a report that would turn into action plan. Within this period, when a weak coalition government was ruling the country, the report which was prepared by bureaucrats determined a road map for Turkey during the impending Iraq war. In the National Security Council (NSC) in August 2002, the four of six important red lines emphasized in the report were about Northern Iraq:

1- Declaration of an independent Kurdish state in the North of Iraq,

2- Mosul and Kirkuk getting under the rule of Kurds,

3- A federal structure that will pave the way for independence of Kurds in Iraq,

4- Iraqi Turkmens not being a primary component of the established structure

(Taştekin, 2006: 262-263).

The red lines were about the constructs that would emerge in Northern Iraq especially after the war and the consequences of the separation of Iraq. Thus, having concerns about the possibility of a probable war disrupting the territorial integrity of Iraq, Turkey made some attempts in the presence of The USA, the Arab countries in the area and Iraq in order to prevent the invasion. These attempts had in fact started five years before the war. As a result of the attempts of İsmail Cem, the Foreign Affairs minister of the time, Neighbourhood Form was established. During the period of Justice and Development Party, which came to power in November 2002, diplomatic meetings were initiated under the name of "the meeting of Iraq's neighbouring countries". The first one was made in İstanbul on 23 January 2003 and a consensus was reached in two important issues: 1-To make 
diplomatic initiations in the presence of Baghdad in order to prevent the invasion of Iraq 2-To undertake attempts to protect the territorial integrity of Iraq if the war cannot be prevented.

However, when it was not possible to prevent the war, decisions were made in the subsequent meetings to "protect the territorial integrity of Iraq" and "to neutralize the terrorist groups in the country which were active in the country and which threatened the neighbouring countries", which reflected the red lines of Turkey (Yeşilyurt, 2013: 405-407)

Turkey was concerned that KRGI would become a tempting factor for uneasy Kurds in Turkey or this government would directly help the separatist Kurds. Thus, Ankara was worried about the emergence of a fully independent and sovereign Kurdish state and that this state would threaten the countries in the region as well as the territorial integrity of Turkey. In fact, in 2002-2003 when the USA decided to start a military operation to Saddam Huseyin regime, Ankara warned Washington that the war would cause the emergence of an autonomous oil-rich state or an independent Kurdish state. Because of these worries, TBMM did not allow USA forces to enter Turkish territory as a result of the voting in TBMM on 1 March 2003. On the other hand, Ankara started active diplomacy in the Middle East. Diplomatic meetings initiated by Abdullah Gül government on 23 January 2003 would continue after the war, too. Meetings were held in Kuwait in February 2004 with the participation of Saudi Arabia, Iran and Syria. These countries which had similar worries with Ankara were included in a United Nations (UN) advisory group by the Kofi Annan secretary general of UN. Ankara made statements with Damascus and Tehran which supported the territorial integrity of Iraq and opposed the establishment of an ethnic based federation in Iraq (Park, 2004: 22-23).

Despite Turkey's aforementioned attempts, different alternatives were assessed when it became certain that the war would break out. By the decisions taken in NSC meeting on 27 December 2002, negotiations were made between G. Bush and A. Gül governments about opening of a front in the North of Iraq. In these negotiations, Ankara emphasized Turkey's "red lines” again as prerequisites. As a result of the negotiations, a memorandum of understanding was signed. According to this memorandum, 60000 American soldiers would enter Iraq from the North and 40000 Turkish soldiers would deploy in Northern Iraq to support the American troops. In addition, the USA would provide 6 billion dollars of financial assistance to Turkey (Tür, 2012: 602). Turkey’s target was to enter Kurdish dominated cities, disarm the Peshmerga,to prevent "demografic change" of Kirkuk and put an end to the quest for autonomy (Rafaat, 2007: 80).

Within this period, there were two different public views discussed on what kind of a path Turkey had to follow. According to the first view, 
Turkey had to enter the war with USA because Turkey’s strategic interests necessitated this. If Turkey did not enter the war, Turkey would not be able to have a say in the future of Iraq, especially Northern Iraq, thus, Kurds would get closer to independence and Turkmens would be deprived of many rights. It was even asserted by some circles that Turkey could get back Mosul and Kirkuk in case of entering the war. The advocators of the opposite view moved from the thesis that the war was not related with the strategic interests of Turkey. In addition, this group emphasized that it was wrong for Turkish soldiers to be under the command of the USA and for American soldiers to settle in Turkey in terms of the understanding of national sovereignty (Tür, 2012: 601). Chief of general staff of the time, Hilmi Özkök summarized the reason for Turkey being out of war in short as "This is not our war. This is not our duty." Özkök stated under which circumstances Turkey would enter a war as "1) There are the elements of Turkish army in Northern Iraq. An attack to these forces. 2) Depending on the developments of the war, emergence of a big refugee influx, 3)An instability that may occur as a result of the attack of one of the armed forces in the area to another or to a civilian...” (Hürriyet, 2003, 27 March).

The most important development that determined Turkey's Northern Iraq policy and Turkey's attitude in its relations with the USA was the rejection of March 1 motion. The motion which rejected the claim of USA forces for using Turkish territory in an operation to Iraq anticipated the operation to be made via Turkey and the reinforcement of Turkey's presence in Northern Iraq (Avc1, 2014: 7). In fact, with the rejection of the motion, it had been clear that Turkey's effect on Northern Iraq, which had been under the supervision of Turkey during 1990s, would decrease. Thus, in order to be able to maintain the position in the region and to prevent any further breakdown in Turkish-American relations, a new motion was accepted on 20 March 2003 which allowed the USA to use the Turkish air field (Tür, 2012: 601).

In negotitations with the USA before 20 march motion, Turkey had laid down as a condition to send 20000 soldiers to Northern Iraq. However, the USA did not approve this demand in line with the agreement with Kurdi groups. In other issues that Turkey was sensitive about, the USA gave a verbal guarantee that "Turkmens would be protected by USA and precautions would be taken against PKK” (Uzgel, 2013: 275). However, 20 March motion did not help to recover Turkish-American relations, with the "Süleymaniye (sack) incident" about four months after this date, one of the most important crises occured in bilateral relations. American soliders attacked the Turkish Special team center in Süleymaniye with 100 peshmergas on 4 July 2003 and detained 11 Turkish soldiers here by throwing a sack on their heads. After the Süleymaniye incident, the USA 
authorities accused Turkey of sabotaging the stability in the region. Within this period, while there was a big chaos and anarchy in the other parts of Iraq, Northern Iraq was partly stable. For this reason, occupation forces had been deployed in the central and South parts of Iraq predominantly. However, American authorities showed that they were in fact disturbed by Turkey's activities in the region and threatened Turkey in a way to end these activities (Tür, 2012: 603). Thus, it was shown that Turkey would not be allowed to operate in the region as it liked, like the 1990s. The USA who had peshmerga forces was confirming its new alliance in the region. On the other hand, attacks were made to institutions of Iraq Turkmen front (ITF) on 4 March (Uzgel, 2013: 277-278). This situation showed that Turkmens were also among those who would pay for the 1 March motion. After the Süleymaniye incident, Turkey's contact offices in the region were shut down and the military powers were decreased in number. Based on these developments, Turkey's military and political influence in the area began to decrease and even to become inefficient (Uzgel, 2013: 283).

After this date, a negative picture had emerged in terms of the foreign policy Turkey wanted to keep in the region and the red lines Turkey had been trying to protect since 1990s. As a result of the cooperation of the USA with Kurds which occured as a result of the fact that they could not get what they wanted from Turkey, The USA armed Kurds against Saddam regime and kind of closed its eyes to the activities of PKK in the region, which influenced the Northern Iraq policy of Turkey to a great extent. Similarly, there occured developments which constituted the most important reservations of Turkey in terms of the national integrity of Iraq (Ögür et al, 2014: 42). Not only was a self-governing state was established in Northern Iraq, but also a loose structured federation started in Iraq. On the other hand, Kurdization of Kirkuk, which was among disputable areas, became a current issue. Because of this during 2004, "Turkey went on making pressure to the USA "to limit the federalism of the future Iraqi state and the degree of autonomy given to any Kurdish federalist region, threatening a difficult and bloody future for any such system”. When the Kurds increased their preassure on the USA and Iraqi central goverment to implement Article 58 of the Transitional Administrative Law, which related to Kirkuk in October 2004, “Turkey spoke of possibly sending troops into northern Iraq, warning that its forces could reach Kirkuk within 18 hours” (Rafaat, 2007: 81).

Within this period, PKK terror intensified again and kept its place among Turkey's national security problems. After the PKK camps in Syria were shut down, the organization entered a period of recovery in Northern Iraq. The new members who joined the organization were trained in various places, mainly Kandil mountain and Mahur camp. On the other hand, the organization which took hold of some of the arms from Saddam army 
prepared to make new actions. PKK broke the cease fire it had declared before in 2004 and speeded up terrorist attacks. During 1990s, a total of 27 operations, some of which were hot pursuits, air attacks while some of which were extensive such as Steel Operation (1995), Hammer Operation (1997) and Dawn Operation (1997) (Aljazeera, 2011, 19 October). However, no extensive operation was undertaken to the area from the aftermath of the invasion until 2007. After the Süleymaniye incident, Turkish Army Forces (TAF) could not launch operations to Northern Iraq without the approval of the USA, except for hot pursuits to terrorists who attacked within the country (Brannen, 2007). Although negotiations were made with Washington and Baghdad on this, no satisfactory results were taken. Methods except intervention were proposed in the negotiations. In negotiations of the authorities of national intelligence service of Turkey with KRGI, Barzani stated that they could cooperate about fighting PKK in the event of "KRGI being recognized by Ankara”. Barzani obviously wanted Ankara to give up on its red lines. Among the other terms Barzani proposed, there was dual citizenship to Kurds on both sides of the border and cooperation between both parties in terms of the fields of education, health and economy. When these terms were not accepted by Ankara, Ankara Erbil relations, which were already tense because of Kirkuk issue began to get worse (Uzgel, 2013: 285). Unlike 1990s, Kurdish leaders who got stronger with the alliance with the USA and who were armed by the USA began to challenge Turkey. In return, Ankara used harsh expressions for PUK. In response to Turkey's persistence in operations during 2006 and 2007 when PKK had increased their activities, Talabani said "we won't hand over even a cat to Turkey", while Barzani stated that "they would not call PKK a terrorist organization, they might call PKK a terrorist organizativn if they did not respond to peace calls" and "they would use their right of self defence if Turkey makes a cross border operation attacks to the region" (Yeni Şafak, 2007, 22 October). Within this period, prime minister Erdoğan likened KRGI to a tribe state and said "I will not negotiate with a tribal leader" (Hürriyet, 2007, 6 June).

When the USA got into a rut in Iraq and started to include the sunnis in this country to the process, it needed Turkey's help. Thus, the USA had to make concessions from some policies by remembering Turkey's sensitivities about Iraq. Because of the agreement reached on 5 November 2007, Bush government gave the green light to Turkey's operation demands despite Baghdad and Erbil (Uzgel, 2013: 289-290). Five air attacks were undertaken to Northern Iraq in 2007 December and 2008 January and February. On 21 February 2008, the first ground operation of 2000s, Güneş Operation, was launched (Aljazeera, 2011, 19 October). However, this operation was both launched under hard winter conditions and also it lasted short, unlike the ones in 1990s. 
Other problems that emerged in the Northern Iraq policy of Turkey within this period were the issues of Kirkuk and Iraqi Turkmens. In Kirkuk, which is a mini version of Iraq, Arabs, Turkmens and Kurds live and each claim a right in this city. Right after the invasion, the plundering of deeds and register offices in this Kirkuk had caused a reaction from Turkey. Foreign Affairs minister Gül and chief of general staff Özkök reminded their American colleagues that the issues guaranteed were not fulfilled and stated that in the event of peshmergas' activities in Kirkuk not being taken under control by American forces, TAF could enter Northern Iraq. These warnings of Turkey were effective in that period and later Kirkuk was taken under control by American forces (Taştekin, 2006: 275). Ankara made initiatives in the presence of Washington to act with coordination in Northern Iraq. However, Washington accepted "a group of Turkish military committee to make examinations in the region" (Uzgel, 2013: 279). Later, when Kurdification policy started in Kirkuk in 2004, Ankara discussed the issue with Kurdi politicians such as Foreign Affairs minister of Iraq, Hoşyar Zebari and Neçirvan Barzani. Kurdi politicians wanted Ankara not to interfere with the issue of Kirkuk any more in return of handing over Osman Öcalan to Turkey. However, when it was understood that Turkey would not make concessions to Kirkuk policy, Mesut Barzani stated that "they could fight if necessary" (İnternethaber, 2004, 19 September). When Mesut Barzani was later called to Ankara to make negotiations, he lightened his tone (Milliyet, 2004, 12 October). In the following periods, Ankara opposed to "Kurdification policy" in Kirkuk and to this city's being connected to KRGI. Ankara defended two theses about the issue of Kirkuk. The first one was that Kirkuk's future had to be determined as a result of negotations between Kurds, Turkmens, Arabs and Asuris living in this city. Another thesis advocated by Turkey was the recommendation of "area with special status" which was one of the four recommendations prepared by UN's Aid mission to Iraq (Uzgel, 2013: 281). Upon understanding that referendum after changing the ethnic structure in the region would serve Kurds, Sunni and Shiite Arabs as well as Turkmens in Iraq expressed their discomforts. As a conclusion, with the persistance of Turkey and Iraq central government and "probably because of the opposition of USA", the referendum in Kirkuk was postponed (Uzgel, 2013: 279).

One of the red lines Turkey declared before the war was about the Turkmens in Iraq. Until the 90s, Turkey did not bring up the Turkmen issue not to interfere with the internal affairs of Iraq. However, after the Gulf War, with the decline in of Saddam regime in the region, Ankara began to watch the Turkmen population in Northern Iraq closely. In 1995, Ankara brought together the 16 Turkmen organizations and pioneered the establishment of Iraqi Turkmen Front (ITF). Turkmens are the third greatest elements in Iraq, 
following Arabs and Kurds. According to their own claims, their population is around 3 million. However, they are not effective enough in Iraq political life. After the invasion, Turkmens were exposed to a lot of oppression and they were excluded from the restructuring process of Iraq. For example, in Iraq temporary administration of 25 people, there was only one Turkmen representative. On the other hand, American troops launched an operation to Tal Afar, where the Turkmens are densely populated, in 2004. Starting from 2005, ITF could not show a significant success in elections in Iraq. The reason for this was the differences in religions, rather than the number of the population. Due to denominational differences, Shia and Sunni groups can act together with Kurd and Arab parties. Party alignments of ITF generally consists of Nationalist Sunni groups. Turkey had not made any demands for Turkmens about minority status and human rights. However, Turkey began to mention these after the invasion, made some interventions asking America to give Turkmens similar rights with Kurds; however, as stated before, “motion crisis” affected Turkmens, too (Uzgel, 2013: 279-280).

Within this period, the only subject Turkey showed success in Northern Iraq was the increase in economic and trade relations with the region. Turkey is the only neighboring country that connects Iraq to both Europe and Mediterranean. On the other hand, the country with the strongest economy among the neighbors of Iraq is Turkey. Since the relations of Syria and Iran, the other neighbors of Iraq, with America had problems Washington included Turkey to the restructuring process of Iraq. In November 2003, a memorandum of understanding was signed between Turkey and Iraq about economic cooperation. Later, Turkish firms also began to make use of the 18,6 billion dolar budget, which was given for the restructuring of Iraq. Thus, trading relations between Turkey and Iraq began to increase fast. While Turkey's export to Iraq was 829 million dollars in 2003, it became 2,845 billion dollars in 2007. The import, which was 113 million dollars in 2003 became 645 million dollars in 2007 (Yeşilyurt, 2013: 408).

\section{Cooperation-based Northern Iraq Policy Period (2008-2015)}

Within the post-invasion period, Turkey kept political relations with KRGI to a minimum level. However, Turkey had influenced the area economically. Northern Iraq's relations with the outer world occured by way of Turkey. The primary reason why Ankara had limited relations with KRGI was the concern that the "loose federal" structuring would cause break-ups in the future. However, Ankara began to see federalism as the healthiest way to maintain the territorial integrity of Iraq. This difference in approach was also reflected in the Northern Iraq policy of Turkey (Kılıç, 2010: 249). Turkey's Northern Iraq policy, which was executed by Special Forces since 1996, 
began to be determined by the Ministry of Foreign Affairs after 2007 (Uzgel, 2013: 290). The decreasing effects of military burocracy in foreign policy can be seen as one of the differences in politics. The government increased its initiative in home and foreign policy and started policies such as "democratic initiative" and "resolution process". Within this period, the increase in political relations with KRGI was a development in parallel with the aforementioned policies. On the other hand, the news that the USA would retreat from Iraq affected Ankara KRGI relations. With the USA retreating from Iraq, Turkey would not come face to face with American powers in operations to the area or the policies to be followed to the region. Thus, Ankara could develop its relations with KRGI and form "sphere of influence" in the region again. KRGI would no longer have the opportunity to stack on Ankara depending on Washington. In addition, Erbil, which was not in good relations with Ankara, would not be able to move freely in the area. In a sense, with the retreat of USA from the region, Ankara and Erbil "would be alone with their fate" in the area. On the other hand, in the event of opposing Ankara, Erbil, which already had bad relations with Baghdad, could have more problems in the area. Antoher reason for Ankara KRGI convergence can be the influence of Iran in governments established after Saddam. As a response to the increasing influence of Iran on Iraq, Turkey headed towards KRGI.

2008 was a turning point in Turkey-KRGI relations. In the NSC on 24 April 2008, a decision was taken that "it was suitable for Turkey's interests to have relations with Iraqi groups and actors" (Balc1, 2014: 1011). The first direct contact between Turkey and PUK occured with the meeting between Turkey's Iraq special representative Murat Özçelik, Prime Ministry Foreign Affairs Chief Advisor Ahmet Davutoğlu and KRGI Prime Minister Neçirvan Barzani. Davutoğlu adviced N. Barzani to leave disputed issues aside and to speak about how both parties could cooperate in economic and political areas, including the solution to terror problem (except military methods) (Charountaki, 2012:192). In fact, this offer showed that Ankara was experiencing a transformation about both fighting PKK and Northern Iraq policy. As a result of this, different from previous Turkey KFGI relations, during the period after 2008, Türkiye-KRGI relations had a "legal, direct and institutionalized" structure and thus, the third phase started in bilateral relations (Charountaki, 2012: 190-191).

Due to these developments, Turkey's national security based foreign policy partly remained in the background which was replaced by economic cooperation priviliged foreign policy (Erkmen, 2015: 173). During prime minister Erdoğan's official visit to Baghdad in July 2008, the agreements between the two countries also show the changes in policy. During this visit, a decision was made to establish Turkey-Iraq High Level Strategic 
Cooperation Council, in which ministers of internal affairs, foreign affairs, energy and trade would take part. In addition, agreements were made to build a pipeline for Iraq natural gas, to increase the capacity of Kirkuk Yumurtalik pipeline and to open new border check-points as well as cooperations in the area of energy. In addition, agreements were also made on security. In November 2008, Trilateral Mechanism to fight terrorism was established between Turkey, Iraq and the USA (Uzgel, 2013: 292) ${ }^{5}$. These agreements show that Turkey was continuing its Northern Iraq policy over Baghdad. During his official visit to Baghdad in March 2009, president Gül met KRGI prime minister Neçirvan Barzani. This development was interpreted as Ankara "recognizing” KRGI. Ankara had left its policy of not negotiating with Kurd politicians from Northern Iraq. In the October of the same year, during the official visit of Erdoğan to Iraq, consulates of Turkish republic were opened in Musul, Erbil and Basra (Uzgel, 2013: 292).

Turkey KRGI trading relations focused on areas such as energy, construction and infrastructure. KRGI's incusion in the energy marketing made Ankara and Erbil closer and caused Turkey to catch three important chances in the field of energy. These were cheaper prices in the field of energy, getting rid of being dependent on some countries in energy import since the enegy resources became varied and becoming an energy transfer center which connected energy rich the Middle East and the Caucasus with Europe that was experiencing energy deficits (Balc1, 2014: 17). At this point, Turkey had a key actor role in integrating Northern Iraq economy with international markets. While the amount of daily raw oil carried with KirkukYumurtalik pipleine was around 133.000 barrels in 2010, this amount rose up to more than 147.000 barrels in 2011 (İnan, 2013: 82). In January 2015, minister of energy and natural resources Taner Y1ldiz stated that the oil flow from Northern Iraq had become as daily 450.000 barrels (Anadolu Ajans1, 2015, 14 January). In 2015, the oil shipping from Northern Iraq had increased almost four times when compared with 2014 (Milliyet, 2016, 26 January). Some agreements were made between Turkey and KRGI in the field of energy. One of the most important of these agreements was the construction of the energy corridor that would combine Northern Iraq oil and natural gas with Kirkuk-Yumurtali pipeline. The construction of this corridor had started after the negotiations between USA, Turkey, Iraq and KRGI (Dünya Bülteni, 2013, 28 November). However, agreements between Turkey and KRGI on the field of energy which excluded Iraq Central Government caused tension in Ankara Baghdad relations. While Ankara claimed that a great number of countries made similar activities in the various places of Iraq, Baghdad stated that "every agreement signed without the approval of

\footnotetext{
${ }^{5}$ For Iraqi based secrity problems for Turkey see.(Akbaş, 2012: 328-329)
} 
central government was illegal” (Enerji Enstitüsü, 2013, 15 May). This situation also caused problems in Ankara Washington relations. Washington was worried that the political structure in Iraq would break more and Washington Baghdad relations would deteriorate (Hürriyet, 2013, 25 February).

Table 1. Export-Import data between Turkey and Iraq between 2003 and 2012 (1000 dollars)

\begin{tabular}{|c|c|c|}
\hline Year & Export & Import \\
\hline 2003 & 829.058 & 41.656 \\
\hline 2004 & 1.820 .802 & 145.575 \\
\hline 2005 & 2.750 .080 & 66.434 \\
\hline 2006 & 2.589 .352 & 121.745 \\
\hline 2007 & 2.844 .767 & 118.702 \\
\hline 2008 & 3.916 .685 & 133.056 \\
\hline 2009 & 5.123 .406 & 120.558 \\
\hline 2010 & 6.036 .362 & 153.476 \\
\hline 2011 & 8.310 .129 & 86.753 \\
\hline 2012 & 10.822 .503 & 149.328 \\
\hline
\end{tabular}

Resource: TSI (Erkmen, 2015: 185-186).

It was stated in Minister of Economy Zafer Çağlayan's remarks about export-import numbers in 2012 that the part of commercial relations between KRGI and Turkey was about $70 \%$ as shown by the numbers in the table above (Erkmen, 2015: 191). As can be seen, a sharp increase was experienced in Turkey's export to the area especially in and after 2008. It is possible to explain this change with developments in both home policy of Turkey and also with development summarized above. As for 2014, KRGI both became the most important energy partner of Ankara and became the actor that enabled a smooth relation with Ankara (Öğür et al. 2014: 52). On the other hand, during the restructuring of the region, meeting the infrastructure and superstructure needs, Turkey private sector had an important part. During the restructuring process, the fact that Turkish private sector firms are the most dominant economic power in the region increases KRGI's economic dependence on Turkey. As for 2013, Turkish firms make up $75 \%$ of the construction sector while they make up $10 \%$ of the energy sector (Üstün, 2013: 2).

KRGI's import products from construction products to electronic devices and basic food are provided by Turkey. The number of trucks passing from Habur increasing four times in 3 months startign from 2009 is significant in terms of showing the fast increase in trading relations (Erkmen, 2015: 177). The momentum gained by the volume of trade developed in especially oil, gas, construction and infrastructure has caused economic 
dependency. Turkey-KRGI relations did not develop only in terms of economy. Thanks to advancements in economy, bilateral relations expanded recently to cover political and even defense dimensions. Ankara's agreements with KRGI caused opposition between PKK and KDP-PUK block (Ögür et al. 2014: 48). According to the agreements, KRGI shut its PKK camps in Northern Iraq, began to pressurize Mahur camp, called for PKK to lay down arms and even announced PKK a terrorist organization, although they denied this later (Uzgel, 2013: 291). In terms of security mechanism, bilateral mechanism (Turkey and KRGI) became more important for Turkey and Turkey and KRGI agreed on the establishment of an operation center in Erbil (Erkmen, 2015: 177). Cross-border operations are still being made to Northern Iraq, although not as much as 90s. Peshmergas also joined the operations in 90s from time to time. Peshmergas do not support the operations made today, however, operations are launched with the approval of KRGI. However, Iraq government began to oppose to Turkey's operations this time (Sputniknews, 2012, 3 October). In 2011 and 2012, Turkey launched cross-border air attacks on PKK camps in Northern Iraq. Again on 19 October 2011, TAF started a hot pursuit to catch the PKK members who ran away after an attack in Hakkâri and entered four kilometers inside Northern Iraq and fought the members of the organization here (Karar, 2015, 25 July). Although these operations were paused during the resolution process, in July 2015 when the armed fighting with PKK restarted, air operation was launched in the area in (İnternethaber, 2015, 24 July), while ground operation was launched in October (NTV, 2015, 14 October). This situation shows that Turkey can intervene to the region as long as relations with KRGI do not worsen.

The ILS threat that emerged recently is another factor that caused the development of military relations between Ankara and Erbil. In October 2014 when ILS advanced to Kobani, Turkey opened a corridor to let Peshmerga forces to move to the area where fights were taking place over Turkey (DW, 2014, 20 October). In 2014, during the official visit to Iraq, prime minister Davutoğlu went to Northern Iraq and went to peshmerga training camp here. Here he said "we will fight shoulder to shoulder" (against terrorists) and showed that there was cooperation between Turkey and KRGI (Haberler, 2014, 21 November). In addition, Turkey supported Peshmerga with arms (İdiz, 2014). Against the threat of ILS starting a new attack on Northern Iraq, a special team of 2000 soldiers of TAF were sent to Başika camp of KRGI. The team's official duty was to train peshmergas (Ergan, 2015, 5 December). However, sending Turkish soldiers to Başika disturbed Baghdad (BBC, 2015, 30 December). In addition, with ILS increasing its influence in the region, USA began to approach PKK differently (Akbaş, 2015: 152). On the other hand, Ankara remains silent 
against Barzani's statements about independence. Countries in the region such as Egypt and Iran opposed to KRGI's statements about independence. Prime minister Erdoğan told Barzani "not to hurry up" and adviced him "to support political balances that will maintain the integrity of the country" (T24, 2014, 15 July).

\section{Conclusion}

It is possible to talk about a great number of factors that affect Turkey's Northern Iraq policy. Some of these are Turkey's historical ties and economic and commercial relations with the area, Turkmen population in the region and Northern Iraq's geopolitical position. Since the Gulf War, Turkey's Northern Iraq policy has been shaped in accordance with "security" parameters. The red lines declared before Iraq's invasion were the formulation of Turkey's security worries. However, the developments in Turkey and Iraq following the invasion have caused the transition from a security based policy to economic cooperation based policy in bilateral relations. It can be seen that Turkey's Northern Iraq policy underwent a big transition especially after 2008. First, security based foreign policy called high politics by realist movement changed into the line advocated by mutual dependency theorists. It is possible to evalaute this change as transition to "win win" model from "zero sum game" model. Within the process, both Ankara and Erbil succeeded in cooperating in some areas including security issues due to the gains in economic area.

However, it can be seen that vital subjects for both actors were shelved. However, there is no guarantee that these issues won't come up again in the future. For example, Ankara did not ever mention giving up the "red lines" emphasized before the invasion of Iraq. Thus, it is not known for sure how Ankara will take KRGI's declaration of independence. On the other hand, it is another problem that KRGI claims right on controversial land. How will Turkey react if the areas densely populated by Turkmens such as Mosul and Kirkuk are included under the sovereignty of KRGI? The point that has to be made is that during the time that has passed from the preinvasion period to our day, the balances in Iraq has taken a quite different form. Turkey is worried that Iran has turned Iraq into its domain. Thus, Turkey may not oppose to Turkmen's living under the sovereignty of KRGI in the case of basic rights being guaranteed. However, it is not clear what kind of a course Ankara Baghdad relations will take under such a circumstance.

Ankara tried to manage its relations with KRGI until 2010 by taking Baghdad into consideration. Until this date, Ankara Erbil relations had been managed through Baghdad. However, recent developments such as agreements between KRGI and Ankara in the field of energy, Turkey's 
training peshmergas and having soldiers in Northern Iraq have disturbed Baghdad. In addition to these, KRGI's independence goal, its goals about Mosul and Kirkuk and KRGI's activities in the field of energy have disturbed Baghdad. These problems can cause war between Baghdad and Erbil in the following years. In the case of Iraq central government getting stronger, it is possible for this government to head towards policies that will ensure the continuity of the country's territorial integrity. In case of a fight and in case of this fight ending in favor of KRGI, Ankara will face its red lines again while in case of a result in favor of central Iraq government, Ankara will be deprived of its economical gains. In addition, Turkey's being close with KRGI does not disturb only Baghdad. Middle East countries except Israel advocate Iraq's territorial integrity. Thus, Turkey’s KRGI policy can influence the bilateral relations of Turkey with some of the countries in the region, mainly Iran.

Another issue that might be a problem in Turkey KRGI relations in the long run is the Syria crisis. Turkey supports the Free Syria Army and Bayır Bucak Turkmens in Syria, while PUK supports Syria Kurds. Recently, Ankara's relations with Syria Kurds have deteriorated and has warned this group not to move to the west of Firat river. This situation was even declared as “red line”. If Ankara's relations with Syria Kurds deteriorate, this situation can be reflected in Turkey PUK relations. Besides all these, it is possible for both actors to solve the aforementioned problems through compromise by highlighting economic cooperation gains.

\section{References:}

1. Akbaş, Zafer (2015) "İkinci Körfez savaşından Günümüze Irak: Aktörler ile Çıkar Çatışmalrının Analizi” Ed. Esra Pakin Albayrakoğlu, Ertan Efegil, Türkiye'nin Yakın Havzasındaki DevletIçi Çatışmaların Analizleri, pp.. 139-172, İstanbul: Gündoğan Yayınları.

2. Akbaş, Zafer (2012) ““"Devlet İnşa Sürecinde Terörle Mücadele Sorunu: Irak Örneği ve Türkiye'ye Etkileri', The Journal of Academic Social Science Studies, ss. 319-332, 5(4).

3. Aljazeera (2011). "TAF'nın ötesi operasyonları",http://www.aljazeera.com.tr/haber/TAFnin-sinir-otesioperasyonlari, (19.10.2011), (retrieved, 12.12.2015).

4. Altunışık, Meliha Benli (2000). "Güvenlik Kıskacında Türkiye-Orta Doğu İlişkileri”. En Uzun On Yll: Türkiye’nin Ulusal Güvenlik ve Dış Politika Gündeminde Doksanl Yıllar. Ed. G. Özcan, Ş. Kut. Ankara: Büke Publishing House, 2nd Print, pp. 329-353.

5. Anadolu Ajansı (2015). “Kuzey Irak'tan ham petrol akışında 37 milyon varile ulaştık", http://www.aa.com.tr/tr/ekonomi/450023-- 
kuzey-iraktan-ham-petrol-akisinda-37-milyon-varile-ulastik, (14.01.2015), (retrieved, 12.12.2015).

6. Avc1, Erkan. (2014). “2003 ABD’nin Irak’1 İşgali Sonrası Türkiye'nin Irak Politikası ve PKK Sorunu (2003-2013)”, Uluslararast Stratejik Baklş Enstitüsü, http://usbed.org/yayinlar/T\%C3\%BCrkiyenin_Irak_Politikas\%C4\%B 1_ve_PKK_Sorunu.pdfs(retrieved 12 10.2015) pp.. 1-19.

7. Bakan, Zerrin Ayşe (2007). "Soğuk Savaş Sonrasında Yeni Güvenlik Teorileri ve Türkiye'nin Güvenlik Algılamaları”, 21. Yüz Yll,ss. pp. 35-50, October December.

8. Balc1, Ali (2014). "Enerji'sine Kavuşan Komşuluk TürkiyeKürdistan Bölgesel Yönetimi İlişkileri”, Seta, 97, pp.. 1-28.

9. Baylis, John (2008). "Uluslararası İlişkilerde Güvenlik Kavramı", Uluslararası Ilisşkiler, 5 (18), pp. 69-85.

10. BBC (2015). "Irak: Türkiye askerlerin çekilmesi yönündeki anlaşmaya uymadı", http://www.bbc.com/ turkce/haberler/ 2015/12/151230_irak_turkiye, (30.12.2015), (retrieved, 12.02.2016).

11. Brannen, Samuel (2007). "Turkish Airstrikes in Northern Iraq", http://csis.org/files/media/csis/pubs/071219_cq_brannen_turkey.pdf, (19.12.2007), (retrieved, 12.12.2015).

12. Canbolat, İbrahim (2002). Avrupa Birliği: Uluslarüstü Bir Sistemin Tarihsel, Teorik, Kurumsal, Jeopolitik Analizi ve Genişleme Sürecinde Türkiye ile Illişkiler. 3rd Print, Bursa: Alfa Publishing House.

13. Canestaro, Nathan A. (2007). "Realism and Transnationalism:CompetingVisions for International Security", Boston University International Law Journal,Vol: 25, pp. 113-162.

14. Charountaki, Marianna (2012). "Turkish Foreign Policy and the Kurdistan Regiona lGovernment". Perceptions, 18 (4), 185-208.

15. Dünya Bülteni (2013). "Petrol anlaşması Maliki'nin gelişine kaldı". http://www.dunyabulteni.net/haber/281554/petrol-anlasmasimalikinin-gelisine-kaldi, (28.11.2013), (retrieved, 12.12.2015).

16. DW (2014). “Türkiye'den Peşmerge'ye Kobani izni”. http://www.dw.com/tr/t\%C3\%BCrkiyeden-pe\%C5\%9Fmergeyekobani-izni/a-18007828, (20.10.2014), (retrieved, 12.12.2015).

17. Enerji Enstitüsü (2013). "Türk-Kürt petrol anlaşması Irak'1 kızdırdı”. http://enerjienstitusu.com/2013/05/15/turk-kurt-petrol-anlasmasiiraki-kizdirdi-2/, (15.05.2013), (retrieved, 12.12.2015).

18. Eralp, Atila (2000), "Uluslararsı İlişkiler Disiplinin Oluşumu: İdealizm Realizm Tartışması", Ed. Atila Eralp, Devlet, Sistem ve Kimlik: Uluslarası İlişkilerde Temel Yaklaşımlar, pp. 57-89, İstanbul, İletişim Publishing House, 3rd Print. 
19. Ergan, Uğur (2015). “Kuzey Irak’ta 2 bin Türk askeri”, Hürriyet ,http://www.hurriyet.com.tr/kuzey-irakta-2-bin-turk-askeri40023349, (05.12.2015), (retrieved, 12.12.2015).

20. Erkmen, Serhat (2015). "İç Etkenler Açısından Türkiye'nin Kuzey Irak Politikasının Dönüşümü’. Bilig, 72, pp. 171-196.

21. Haberler (2014). "Davutoğlu, Peşmerge Eğitim Kampını Ziyaret Etti”. http://www.haberler.com/davutoglu-pesmerge-egitim-kampiniziyaret-etti-6709237-haberi/,

22. ( 21.11.2014) (retrieved 10.11.2015).

23. Hürriyet (2003). "Dilerim dostlarımız bize muhtaç olmazlar". http://webarsiv.hurriyet.com.tr/2003/03/27/ 267341.asp, (27.03.2003).

24. Hürriyet (2007). "Erdoğan: Kabile reisi ile görüşmem”. http://www.hurriyet.com.tr/erdogan-kabile-reisi-ile-gorusmem6662036, (06.06.2007). (retrieved 10.11.2015).

25. Hürriyet (2013). “Irak bölünmesin ama”. http://www.hurriyet.com.tr/irak-bolunmesin-ama-22676015, (25.02.2013), (retrieved 10.11.2015).

26. İdiz, Semih (2014). “Ankara ve Bağdat ilişkilerde temiz sayfa açıyor". http://www.al-monitor.com/pulse/tr/originals/ 2014/11 /turkey-iraq-new-page-davutoglu-visit.htm. (retrieved 10.11.2015).

27. İnan, Aybüke (2013). "Kerkük-Yumurtalık Petrol Boru Hattı ve Türkiye Irak İlişkileri (1973-2011)”. Ortadoğu Analiz, 5(56), pp. 6885.

28. Internethaber (2004). “Barzani'den ahlaksiz teklif”. http://www.internethaber.com/barzaniden-ahlaksiz-teklif1088289h.htm, (19.09.2004), (retrieved 10.11.2015).

29. Internethaber (2015). "PKK operasyonu! Türkiye bombaladı!". http://www.internethaber.com/pkk-operasyonu-turkiye-bombaladi803282h.htm, (24.07.2015), (retrieved 10.11.2015).

30. Karar (2015). “Türkiye 3 y1l sonra ilk kez PKK'ya sınır ötesi operasyon yaptı". http://www.karar.com/gundem-haberleri/turkiye-3yil-sonra-ilk-kez-pkkya-sinir-otesi-operasyon-yapti-gun-gun-sinirotesi-operasyonlar, (25.07.2015), (retrieved 10.11.2015).

31. Kilıç, Kutbettin (2010). "Kuzey Irak: Bir Etnik Sorunun Arkeolojisi" Ed. Kemal İ., Burhanettin D. and Muhittin A., Dünya Çatışmaları: Çatışma Bölgeleri ve Konuları. Vol I, pp. 223-255, Ankara: Nobel Publishing House.

32. Mearsheimer, John J. (2002). "Realism Real World andthe Academy”, in Michael Brecher and Frank P. Harvey, eds., Realism and Institutionalism in International Studies (AnnArbor: TheUniversity of Michigan Press, 2002), 
http://mearsheimer.uchicago.edu/pdfs/A0029.pdf pp. 23-33, (retrieved 10.11.2015).

33. Milliyet (2004). “Barzani: Fırça için Ankara’ya çağrıldım”. http://www.milliyet.com.tr/barzani--firca-icin-

ankarayacagrildim/siyaset/ haber detay arsiv/12.10.2004/ 90975/default.htm, (12.10.2004), (retrieved 10.11.2015).

34. Milliyet (2016). "Irak'tan Türkiye'ye petrol sevkiyatında rekor artış”. http://www.milliyet.com.tr/irak-tan-turkiye-ye-petrol/ekonomi/ detay/2184613 /default. htm, (26.01.2016), (retrieved 15.02.2016).

35. NTV (2015). “Kuzey Irak'ta sizma operasyonu”, http://www.ntv.com.tr/turkiye/kuzey-irakta-sizma-perasyonu, U1m7bwbjn0CANwVegwfmzQ? ref=infinite, (14.10.2015).

36. Öğür, Berkan, Baykal, Zana and Balcı, Ali (2014). "Kuzey IrakTürkiye İlişkileri: PKK, Güvenlik ve İşbirliği’”. Ortadoğu Araştırmaları Merkezi, 1, http://ormer.sakarya.edu.tr/wpcontent/uploads/2014/08/rapor-film-net-1.pdf. (retrieved 11.09.2015).

37. Park, Bill (2004). “Iraq's Kurds and Turkey: Challenges for US Policy”, Parameters, pp.. 18-30.

38. Rafaat, Aram (2007) "U.S. -Kurdish Relations in Post-Invasion Iraq”, Middle East Review of International Affairs, 11 (4 ) December.

39. Rana, W. (2015). "Theory of ComplexInterdependence: A Comparative Analysis of Realist and Neoliberal Thoughts", International Journal of Business and Socia IScience, 6 (2), pp. 290297.

40. Robin Mills (2016), Under the Mountains: Kurdish Oil and Regional Politics, https://www.oxfordenergy.org/wpcms/wpcontent/uploads/2016/02/Kurdish-Oil-and-Regional-Politics-WPM63.pdf (retrieved 10.11.2016).

41. Sancak, Kadir "Güvenlik Kavramı Etrafındaki Tartışmalar ve Uluslararası Güvenliğin Dönüşümü”, Sosyal Bilimler Dergisi, http://www.ktu.edu.tr/dosyalar/sbedergisi_69519.pdf pp. 123-134 (retrieved 07.10.2015)

42. Sputniknews (2012). "Irak'tan "askeri üssü boşaltın"resti”". http://tr.sputniknews.com/rsfmradio. com/2012 _10_03 /Irak-Turkuslerini-kapatmak-istiyor/, (03.10.2012), (retrieved 11.09.2015).

43. Şahin, Mehmet (2006). "2003 Irak Savaşı ve Iraklı Kürtler”. II. Körfez Savaşı. Ed. M. Şahin and M. Taştekin. Ankara: Platin Press, pp. 283-305.

44. Tanrisever, Oktay F. (2005). “Güvenlik”, Ed. Atila Eralp, Devlet ve Ötesi: Uluslarası Ilişkilerde Temel Kavramlar, pp. 107-125, İstanbul, İletişim Publishing House. 
45. Taştekin, Mesut (2006). "Türk Diş Politikasında 2003 Irak Savaşı”.II. Körfez Savaşı.Ed. M. Şahin and M. Taştekin. Ankara: Platin Press, pp. 245-282.

46. Tellis, Ashley J. (2006-07). "Trade, Interdependence, and Security in Asia”, Strategic Asia, http://nbr.org/publications/strategic_asia/pdf/SA06_Tellis.pdf. pp.325. (retrieved 11.09.2015).

47. Tür, Özlem (2012). " Türkiye'nin Irak ve Suriye İlişkileri”. XXI. Yüzyılda Türk Dış Politikasının Analizi. Eds. F. Sönmezoğlu et al., İstanbul: Der Press,.pp. 593-615.

48. T24 (2014). "Erdoğan'dan Barzani'ye: Bağımsız Kürdistan için acele etmeyin”. http://t24.com.tr/haber/erdogandan-barzaniye-bagimsizkurdistan-icin-acele-etmeyin, 264373, (15.07.2014), (retrieved 11.09.2015).

49. Uzgel, İlhan (2013). “ABD ve NATO’yla İlişkiler” Ed. B. Oran, Türk Dış Politikası, Kurtuluş Savaşından Bugüne Olgular, Belgeler, Yorumlar, Vol III: 2001-2012, İletişim Publishing House, 2nd Print, pp 249-337.

50. Üstün, Nazlı (2013). "Türkiye-Kuzey Irak İlişkileri ve Ekonomik Yansimaları". Konya Ticaret Odas1, pp. 1-12, http://www.kto.org.tr/d/file/turkiye-\%E2\%80\%93-kuzey-irakiliskileri-ve-ekonomik-yansimalari.pdf. (retrieved 11.09.2015).

51. Voller, Yaniv (2012). From Rebellion to De Facto Statehood: International and Transnational Sources of The Transformation of The Kurdish National Liberation Movement in Iraq Into The Kurdistan Regional Government. Phd Thesis. London: London School of Economics and Political Science.

52. Yeni Şafak (2007). "Türkiye'ye bir kedi bile teslim etmeyiz". http://www.yenisafak.com/gundem/turkiyeye-bir-kedi-bile-teslimetmeyiz-76356, (22.10.2007) (retrieved 11.09.2015).

53. Yeşilyurt, Nuri (2013). “Orta Doğuyla İlişkiler” Ed. B. Oran, Türk Dış Politikası, Kurtuluş Savaşından Bugüne Olgular, Belgeler, Yorumlar, Vol III: 2001-2012, İletişim Publishing House, 2nd Print, pp 401-403. 


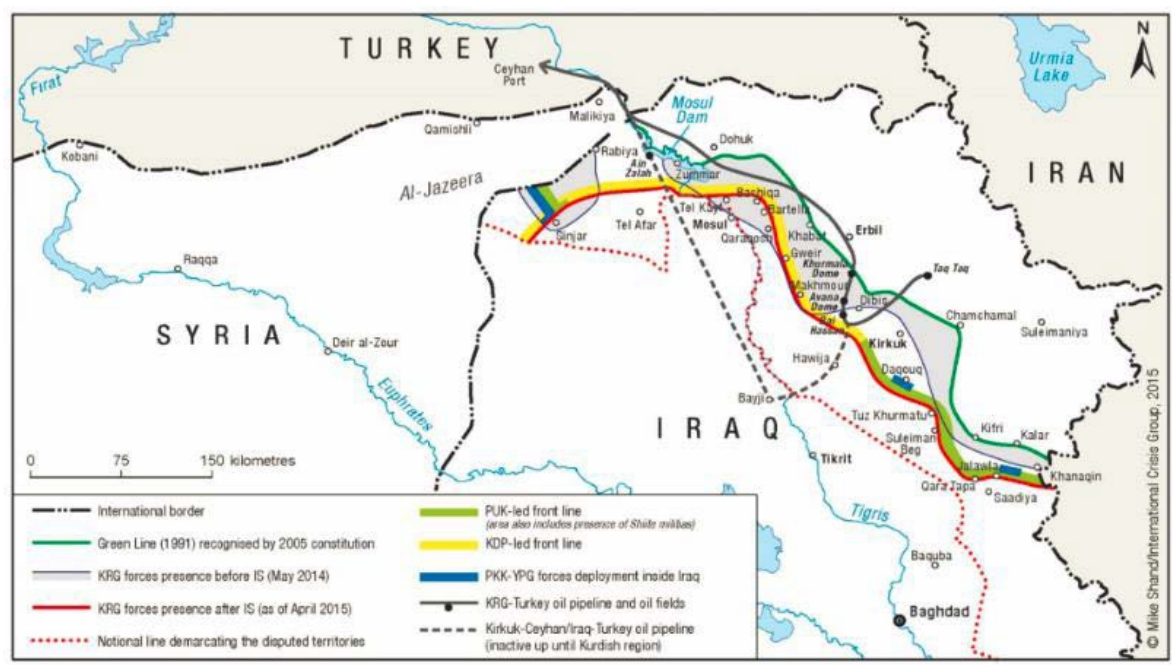

Figure 1: Political and military boundaries of the Kurdish region of Iraq (as of April 2015), (Mills, 2016: 5)

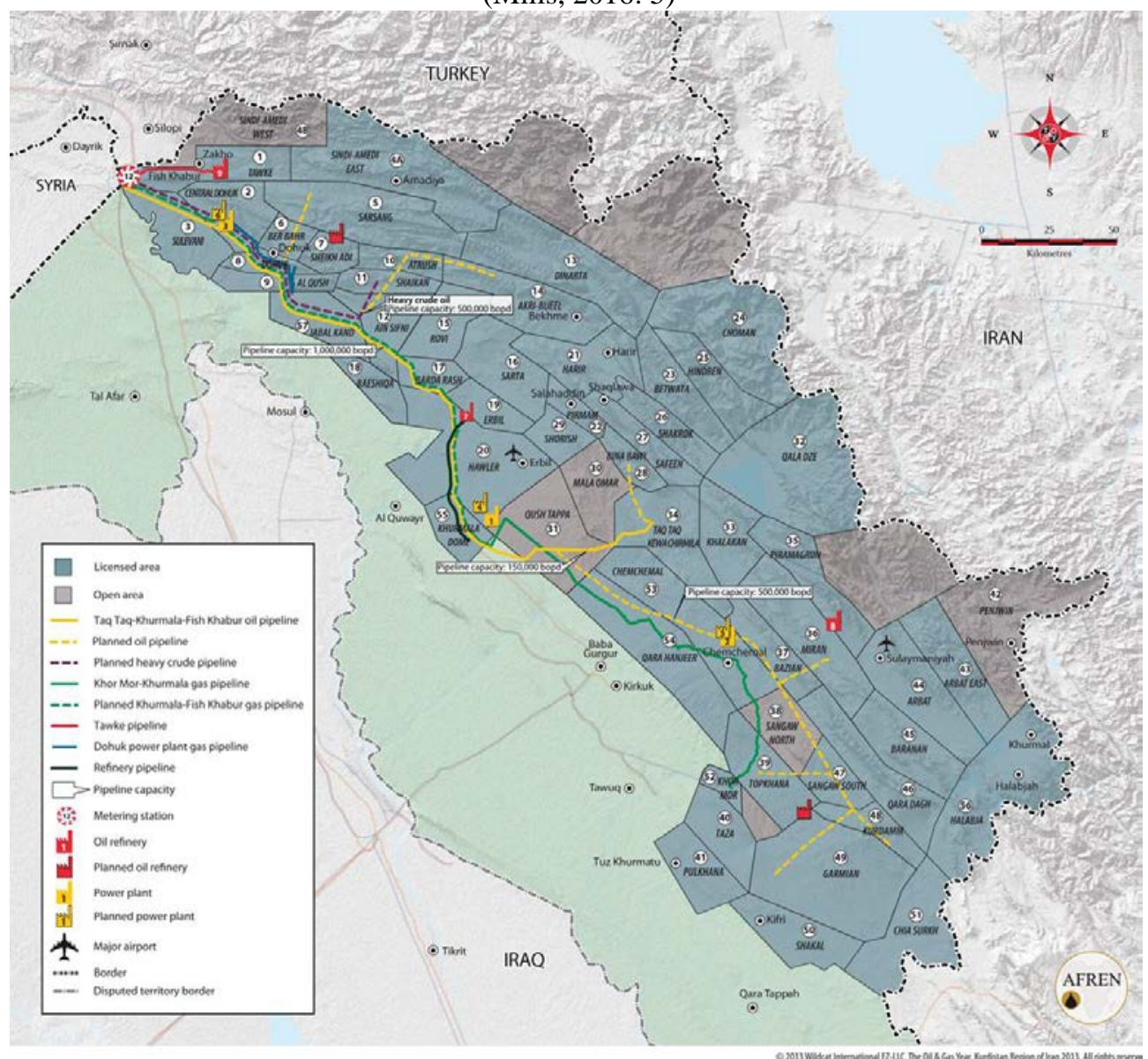

Figure 2: KRI oil and gas infrastructure (Mills, 2016: 22) 